\title{
THE FUNCTIONAL CAPACITY OF THE KIDNEY DENERVATED BY AUTOTRANSPLANTATION IN THE DOG ${ }^{1}$
}

\author{
BY NEAL S. BRICKER,² RALPH A. STRAFFON, ${ }^{3}$ EDWARD P. MAHONEY, AND \\ JOHN P. MERRILL \\ (From the Department of Medicine, Peter Bent Brigham Hospital and Harvard Medical School, \\ Boston, Mass.)
}

(Submitted for publication August 28, 1957; accepted October 17, 1957)

The influence of renal nerves on the renal tubular transport of sodium chloride has been a source of controversy for many years. Both conceptual and methodologic differences have contributed to the continuing conflict. The conceptual disagreements concern the primacy of glomerular filtration rate changes (as opposed to intrinsic alteration in tubular transport) in explaining differing rates of sodium excretion between denervated and innervated kidneys in the same animals. The methodologic problems relate to the validity of the procedures conventionally employed for denervation. The first of these, interruption of all visible nerves entering at the hilus, has been criticized because of the possibility that some nerve fibers may be left intact. The second, section of the splanchnic nerves, has been criticized because splanchnic structures other than the kidneys lose their nerve supply. The contention of Quinby (1) that complete denervation depends upon section and resuture of renal artery, vein and ureter has been frequently cited (2).

Studies have recently been reported on a human kidney which fulfilled Quinby's criteria for denervation (3). This organ, which had been transplanted from one identical twin to another, was totally denervated at the time of transplantation, and the denervation was restricted to the involved organ. The objections to conventionally denervated kidneys were thereby obviated. The data demonstrated that the transplanted kidney could accomplish the majority of functions examined

1 Supported in part by the Howard Hughes Medical Institute; the Medical Research and Development Board, Office of the Surgeon General, Department of the Army; the United States Public Health Service; and the American Heart Association.

2 Present address: Washington University Medical School, St. Louis, Missouri.

3 Present address : Department of Surgery, University of Michigan Medical School, Ann Arbor, Michigan. in a normal or near-normal manner. However, no definitive conclusions regarding the role of renal nerves on sodium transport could be drawn. The present studies were initiated in order to further explore this problem, as well as to gain additional information about the functional capabilities of transplanted kidneys.

Experiments have been performed on dogs in which one kidney was autotransplanted from the renal fossa to the iliac fossa. The opposite kidney in each animal served as the control organ. Individual functions of both kidneys were examined simultaneously at intervals, both before and after transplantation. Similar studies were performed on two dogs in which one kidney was denervated conventionally. Comparison of the experiments on the kidney conventionally denervated with those on the transplanted kidney has provided a means of evaluating the former as an experimental model.

\section{METHODS}

Studies were performed on eight female mongrel dogs in which the urinary bladder was divided longitudinally between the ureteral orifices. Each half was then fashioned into a discrete hemibladder (4). The two kidneys of each animal were thereby provided with individual bladders drained by permanent polyethylene tubes protruding through stab wounds in the anterior abdominal wall. With proper care to prevent plugging of the catheters, such animals have been found to remain healthy and vigorous indefinitely. With one exception, each animal was subjected to from one to three preliminary clearance studies (prior to denervation) in order to define the functional interrelationships of the two kidneys. In six dogs, one kidney was autotransplanted (and thereby denervated) from the renal fossa to the iliac fossa using a procedure similar to that described by Murray, Lang, Miller, and Dammin (5). The ureter of each transplanted kidney was reimplanted into its own hemibladder. In two dogs denervation was accomplished by stripping the adventitia from the renal vessels and dissecting the kidney from adherent and adjacent tissue 
which might contain renal nerves. The contralateral kidney in each animal was left intact to serve as the control organ. Subsequent to the surgical procedure, from one to four follow-up studies were performed. The earliest of these was eight days postdenervation and the latest 163 days postdenervation. Thirteen of the 18 postdenervation experiments were made within 23 days of denervation.

Standard renal clearance procedures were employed. Glomerular filtration rate (GFR) was determined by exogenous creatinine clearance $\left(\mathrm{C}_{\mathrm{or}_{\mathbf{r}}}\right)$ and effective renal plasma flow (ERPF) by $p$-aminohippurate clearance $\left(\mathrm{C}_{\mathbf{P A B}}\right)$. The animals were studied in the unanesthetized state and in the standing position, supported by an abdominal sling with openings for the limbs and catheters. The height of the sling was adjusted so as to allow the legs to touch the base of a table.

Urine collection periods were concluded with water and/or air injections $(0.5 \mathrm{ml}$.), using $2 \mathrm{ml}$. syringes which adapted to the catheters. Heparinized venous blood samples were drawn at the mid-point of each period through an inlying polyethylene catheter in the external jugular vein. Because of the necessity for removing large volumes of blood on multiple occasions, the red cells from each blood sample were resuspended in physiologic saline, filtered through sterile gauze and reinfused. The analytic methods employed have been described previously (3).

Three types of experiments were principally employed to examine electrolyte excretion: 1) Sustained isotonic expansion of extracellular fluid (ECF) volume was induced by the infusion of a simulated ECF solution at $8.8 \mathrm{ml}$. per minute. The total volume of infusate was calculated to expand ECF by 25 to 50 per cent. In order

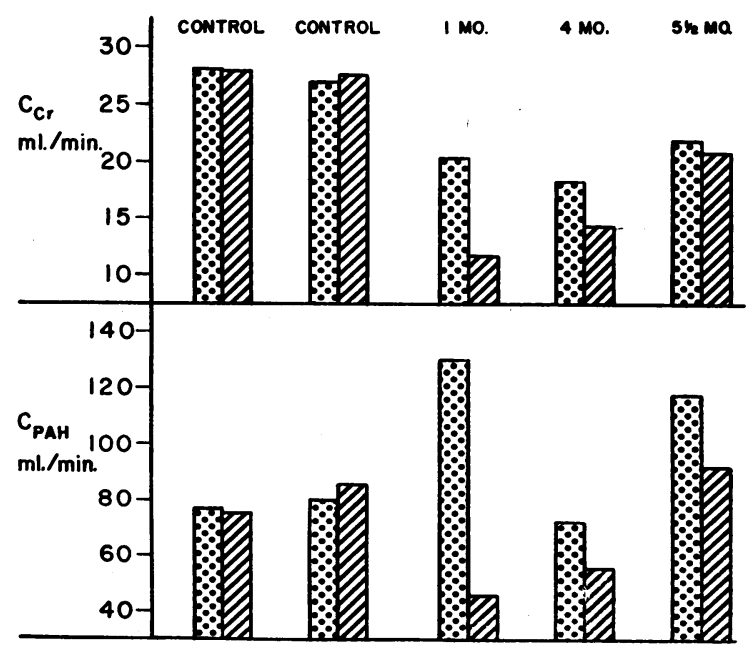

Fig. 1. Serial Changes in Billateral Renal Hemodynamics Following Unilateral AutotransPLANTATION

Stippled bars represent intact kidney, cross-hatched bars transplanted kidney. Control studies were performed before unilateral transplantation. to maintain the expanded volume, as well a: to preserve the constancy of plasma $\mathrm{Na}$ and $\mathrm{Cl}$ concentrations, the estimated urinary losses of sodium, chloride and water were replaced throughout the experiment hy the infusion of synthetic urine solutions as described by Wesson, Anslow, Raisz, Bolomey, and Ladd (6). During the final three clearance periods (after the completion of expansion), $50 \mathrm{~m} \mu$ of vasopressin (Pitressin(B) was injected as a priming dose and $1 \mathrm{~m} \mu$ per minute was delivered in the sustaining infusion of creatinine and PAH. 2) Hypertonic expansion of ECF volume was induced by the infusion of three per cent saline at $5 \mathrm{ml}$. per minute. In one study, ECF volume was expanded with hypotonic saline. 3) Anesthesia was induced by the intravenous administration of sodium pentobarbital (30 mg. per Kg.) after the third clearance period.

In two studies, sodium excretion was examined follusiing the intravenous administration of mercurial diuretic : In the majority of experiments, the first three clearar $\mathrm{e}$ periods were control periods and were obtained $u 1$. er conditions of a diuresis induced by the previots administration of water $(20$ to $30 \mathrm{ml}$. per $\mathrm{Kg}$.) by stuinach tube.

\section{RESULTS}

\section{Transplanted kidneys}

Renal hemodynamics. In the initial studies following transplantation, values for $\mathrm{C}_{\mathbf{C r}}$ and $\mathrm{C}_{\mathbf{P A H}}$ for the transplanted kidneys were appreciably below their respective control levels. The changes varied from a 44 per cent decrease to almost complete suppression of function in one dog. In one of the six animals, clearance values were higher for the transplanted than the intact kidney; but unfortunately, this was the single dog in which no control studies were available. In most animals, reciprocal changes in clearance values occurred in the intact kidney, with $\mathrm{C}_{\mathbf{P A B}}$ increasing proportionally more than $\mathrm{C}_{\mathrm{Cr}}$. Filtration fractions typically decreased bilaterally and equally. In the transplanted kidneys, this change resulted from a greater decrease in $\mathrm{C}_{\mathrm{Cr}}$ than $\mathrm{C}_{\mathbf{P A H}}$, whereas in the intact kidneys it represented a greater increase in $\mathrm{C}_{\mathbf{P A B}}$ than $\mathrm{C}_{\mathbf{C r}}$.

In the three dogs in which serial studies were performed following transplantation, clearance values increased with time. In two of these the values for the two kidneys approached equality. In Figure 1 data are shown for an animal followed for 163 days subsequent to autotransplantation.

The transplanted kidney maintained its capacity to increase filtration rate and renal plasma 
TABLE I

Simultaneous effects of volume expansion on the glomerular filtration rate in transplanted and intact kidneys

\begin{tabular}{|c|c|c|c|c|c|c|c|}
\hline \multirow[b]{2}{*}{ Dog } & \multirow{2}{*}{$\begin{array}{l}\text { Day after } \\
\text { transplant }\end{array}$} & \multirow{2}{*}{$\begin{array}{l}\text { Clearance } \\
\text { period }\end{array}$} & \multirow[b]{2}{*}{ Infusate } & \multicolumn{2}{|c|}{$\begin{array}{c}\mathrm{CCr}^{*} * \\
m l . / m i n\end{array}$} & \multicolumn{2}{|c|}{$\begin{array}{l}\text { Per cent increase from } \\
\text { mean control value }\end{array}$} \\
\hline & & & & TK† & I K $\ddagger$ & TK & IK \\
\hline \multirow[t]{2}{*}{$\mathrm{RQ}$} & \multirow[t]{2}{*}{20} & \multirow[b]{2}{*}{$\begin{array}{c}1-3 \\
\text { (mean) } \\
4 \\
5 \\
6 \\
7 \\
8 \\
9 \\
10 \\
11 \\
12 \\
13\end{array}$} & $0.9 \% \mathrm{NaCl}$ at $1.5 \mathrm{ml} . / \mathrm{min}$ & 20.9 & 44.5 & & \\
\hline & & & $\begin{array}{l}\text { Isotonic (simulated ECF) } \\
\text { solution at } 8.8 \mathrm{ml} . / \mathrm{min} \text {. }\end{array}$ & $\begin{array}{l}20.8 \\
19.2 \\
19.2 \\
21.9 \\
28.4 \\
29.4 \\
32.9 \\
29.3 \\
26.6 \\
18.3\end{array}$ & $\begin{array}{l}39.9 \\
45.6 \\
41.8 \\
51.4 \\
54.1 \\
64.6 \\
60.2 \\
53.4 \\
57.8 \\
50.0\end{array}$ & $\begin{array}{r}4.8 \\
35.9 \\
40.7 \\
57.4 \\
40.2 \\
27.3\end{array}$ & $\begin{array}{r}2.5 \\
\\
15.5 \\
21.6 \\
45.2 \\
35.3 \\
19.8 \\
29.9 \\
12.4\end{array}$ \\
\hline \multirow[t]{2}{*}{ LG } & \multirow[t]{2}{*}{56} & $\begin{array}{c}1-3 \\
\text { (mean) }\end{array}$ & $0.9 \% \mathrm{NaCl}$ at $1.5 \mathrm{ml} . / \mathrm{min}$ & 4.4 & 16.1 & & \\
\hline & & $\begin{array}{l}4 \\
5 \\
6 \\
7 \\
8\end{array}$ & $3 \% \mathrm{NaCl}$ at $5.0 \mathrm{ml} . / \mathrm{min}$ & $\begin{array}{l}6.8 \\
6.7 \\
7.8 \\
7.8 \\
9.2\end{array}$ & $\begin{array}{l}23.2 \\
24.5 \\
26.9 \\
27.2 \\
30.3\end{array}$ & $\begin{array}{r}54.5 \\
52.3 \\
77.3 \\
77.3 \\
109.1\end{array}$ & $\begin{array}{l}44.1 \\
52.2 \\
67.1 \\
68.9 \\
88.2\end{array}$ \\
\hline
\end{tabular}

* $\mathrm{C}_{\mathrm{Cr}_{\mathrm{r}}}=$ Creatinine clearance.

$+\mathrm{TK}=$ Transplanted kidney.

I IK = Intact kidney.

flow during ECF expansion regardless of the absolute level of these functions at the time of the study. Moreover, the increases in clearance values for the transplanted kidneys were generally proportional to those noted for the intact kidneys. That these changes were a function of volume expansion rather than the particular infusate employed is suggested by the similarity of responses noted following the infusion of hypotonic, isotonic and hypertonic solutions. Two representative experiments are shown in Table I.

Following the induction of anesthesia, the GFR in normally innervated kidneys often decreases. In kidneys denervated by conventional methods, this anticipated decrease in clearance values has frequently been absent. The results of induction of anesthesia with intravenous sodium pentobarbital, after three control periods, in a dog with one kidney autotransplanted are shown in Figure 2. The intact (normally innervated) kidney sustained a decrease in $\mathrm{C}_{\mathrm{Cr}}$, whereas the values for the transplanted kidney remained essentially constant. This response was not invariable, however, and in Table II the results of an experiment in which GFR decreased relatively more for the transplanted than intact kidney are shown.

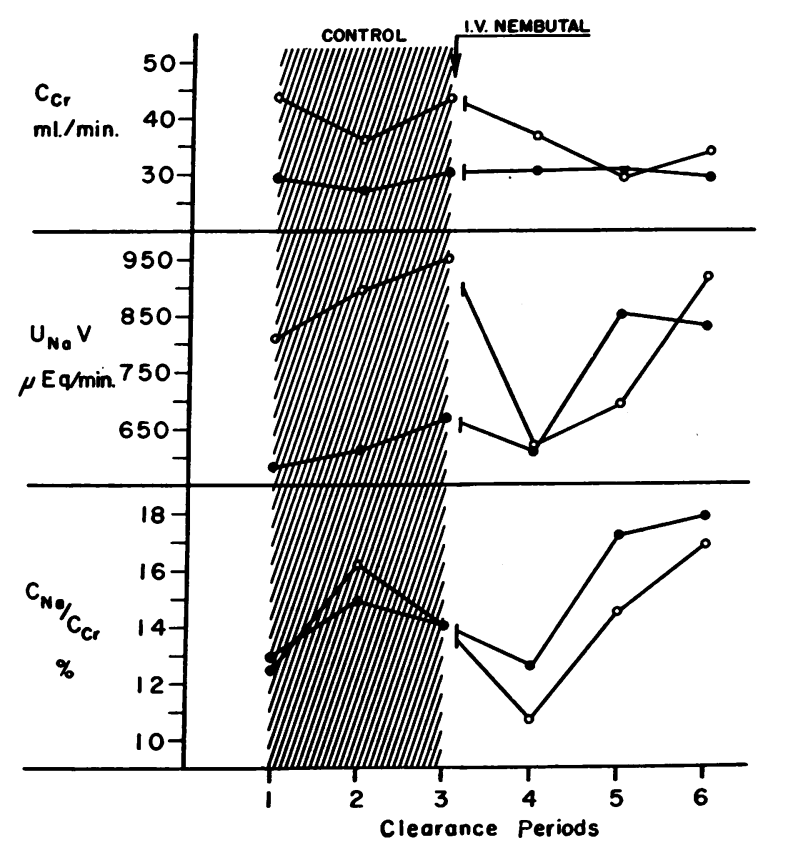

Fig. 2. Effects of Anesthesia Bilaterally Following Unilateral Transplantation

Open circles represent intact kidney, closed circles transplanted kidney. $\mathrm{U}_{\mathrm{Na}} \mathrm{V}$ refers to minute rate of $\mathrm{Na}$ excretion and $\mathrm{C}_{\mathrm{Na}} / \mathrm{C}_{\mathrm{Cr}}$ to percentage of filtered sodium excreted. Donnan factor for sodium was 0.95 . 
TABLE II

Effects of anesthesia on the creatinine clearance, sodium and potassium excretion rates during 3 per cent saline infusion in transplanted and intact kidneys

\begin{tabular}{|c|c|c|c|c|c|c|c|c|c|c|c|c|c|}
\hline \multirow[b]{2}{*}{ Dog } & \multirow[b]{2}{*}{ Day } & \multirow{2}{*}{$\begin{array}{l}\text { Clear- } \\
\text { ance } \\
\text { period }\end{array}$} & \multicolumn{2}{|c|}{$\underset{(m l . / m i n .}{\mathrm{Cc}_{\mathbf{r}}}$} & \multirow{2}{*}{$\underset{\mathrm{TK} \ddagger / \mathrm{IK} \delta}{\mathrm{C} \mathrm{Cr}_{\mathrm{r}}}$} & \multicolumn{2}{|c|}{$\begin{array}{c}\mathrm{U}_{\mathrm{NaV}_{\mathrm{a}}} * \\
(\mu E q . / \min .)\end{array}$} & \multicolumn{2}{|c|}{$\begin{array}{c}\text { Per cent FL† } \mathrm{Na} \\
\text { excreted } \\
\end{array}$} & \multirow{2}{*}{$\begin{array}{c}\text { Per cent } \\
\text { FL† Na } \\
\text { excreted } \\
\text { TK } \ddagger / I K \S\end{array}$} & \multicolumn{2}{|c|}{$\underset{(\mu \text { Eq./min. })}{\mathrm{U}_{\mathrm{KV}} \dagger}$} & \multirow{2}{*}{$\begin{array}{c}\mathrm{UKV}_{\mathrm{K}} \dagger \\
\mathrm{TK} \neq / \mathrm{IK}\end{array}$} \\
\hline & & & TK‡ & IK\& & & TK‡ & IK\& & TKł & IK\& & & TK‡ & IK8 & \\
\hline \multirow[t]{2}{*}{ PW } & 21 & $\begin{array}{l}1 \\
2 \\
3 \\
4\end{array}$ & $\begin{array}{l}20.8 \\
23.1 \\
21.6 \\
20.4\end{array}$ & $\begin{array}{l}11.7 \\
16.2 \\
14.2 \\
14.0\end{array}$ & $\begin{array}{l}1.78 \\
1.43 \\
1.52 \\
1.46\end{array}$ & $\begin{array}{l}118 \\
209 \\
273 \\
294\end{array}$ & $\begin{array}{r}77 \\
176 \\
245 \\
244\end{array}$ & $\begin{array}{l}4.2 \\
6.4 \\
8.1 \\
9.1\end{array}$ & $\begin{array}{r}4.8 \\
7.3 \\
11.5 \\
10.9\end{array}$ & $\begin{array}{l}0.88 \\
0.88 \\
0.70 \\
0.83\end{array}$ & $\begin{array}{l}28.2 \\
47.5 \\
36.5 \\
31.7\end{array}$ & $\begin{array}{l}11.1 \\
28.2 \\
28.6 \\
24.3\end{array}$ & $\begin{array}{l}2.54 \\
1.68 \\
1.28 \\
1.30\end{array}$ \\
\hline & Mean & $1-4$ & 21.5 & 14.0 & 1.54 & 223 & 186 & 7.0 & 8.6 & 0.81 & 36.0 & 23.1 & 1.56 \\
\hline \multicolumn{14}{|c|}{ Intravenous administration of $\mathrm{Na}$ pentobarbital (30 mg./Kg.) } \\
\hline & & $\begin{array}{l}5 \\
6 \\
7\end{array}$ & $\begin{array}{l}14.5 \\
21.3 \\
19.3\end{array}$ & $\begin{array}{l}12.8 \\
13.8 \\
12.8\end{array}$ & $\begin{array}{l}1.13 \\
1.54 \\
1.51\end{array}$ & $\begin{array}{r}96 \\
243 \\
278\end{array}$ & $\begin{array}{l}138 \\
215 \\
308\end{array}$ & $\begin{array}{l}3.8 \\
6.6 \\
8.1\end{array}$ & $\begin{array}{r}6.2 \\
9.0 \\
13.6\end{array}$ & $\begin{array}{l}0.61 \\
0.73 \\
0.60\end{array}$ & $\begin{array}{l}12.6 \\
28.9 \\
20.1\end{array}$ & $\begin{array}{l}12.9 \\
12.5 \\
20.0\end{array}$ & $\begin{array}{l}0.98 \\
2.31 \\
1.01\end{array}$ \\
\hline & Mean & $5-7$ & 18.4 & 13.1 & 1.40 & 206 & 220 & 6.2 & 9.6 & 0.65 & 20.5 & 15.1 & 1.36 \\
\hline \multicolumn{3}{|c|}{$\begin{array}{l}\text { Per cent change in } \\
\text { mean values }\end{array}$} & -14.4 & -6.4 & & -7.5 & +18.2 & -11.4 & +11.6 & & -43 & -34.6 & \\
\hline
\end{tabular}

* UV $=$ Minute rate of excretion.

$\dagger \mathrm{FL}=$ Filtered load.

$\ddagger \mathrm{TK}=$ Transplanted kidney.

$\S \mathrm{IK}=$ Intact kidney.

Concentration and dilution. Values for free water clearance $\left(\mathrm{C}_{\mathrm{H}_{2} \mathrm{O}}\right)$ during isotonic expansion of ECF volume are shown in Figure 3. A pro-

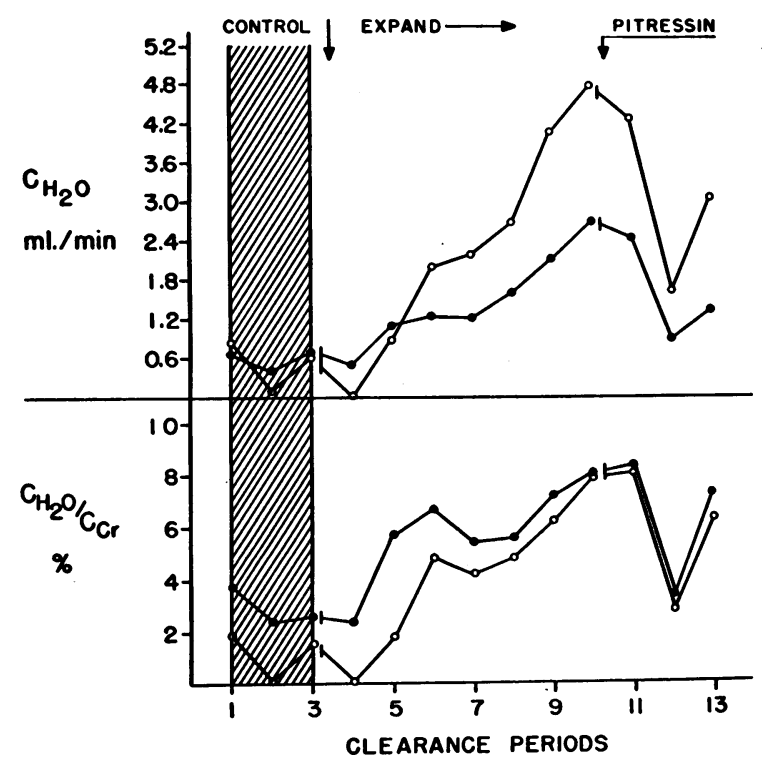

Fig. 3. Free Water Clearance During ECF Expansion Three Weeks Post-transplant

Open circles represent intact kidney, closed circles transplanted kidney. Each point is the value of a 15 to 30 minute clearance period. $\mathrm{C}_{\mathrm{H}_{2} \mathrm{O}}$ refers to free water clearance. gressive increase occurred for both the transplanted and the intact kidneys. Following the initiation of Pitressin ${ }^{\circledR}$ infusion, $\mathrm{C}_{\mathrm{H}_{2} \mathrm{O}}$ fell bilaterally. When values for free water clearance are factored by the respective values for filtered water (lower half of Figure 3), the ratios for the two kidneys approach equality and remain comparable during Pitressin ${ }^{\circledR}$ infusion. In a similar experiment on a different dog, the urine from both kidneys became concentrated during the infusion of Pitressin ${ }^{\circledR}$. The values for solute free water $a b-$ stracted $\left(\mathrm{T}^{\mathrm{c}} \mathrm{H}_{2} \mathrm{O}\right)$ were numerically greater for the intact kidney, but so also was the filtration rate, and the ratios $\mathrm{T}^{\mathrm{c}} \mathrm{H}_{2} \mathrm{O} / \mathrm{C}_{\mathrm{Cr}}$ were equal for the two kidneys.

Sodium excretion. Values for sodium excretion rates during the control clearance periods (fasting state, without ECF expansion) were greater in some experiments for the transplanted kidneys (despite lower filtration rates) than for the control kidneys. This was not a consistent finding, however, either for the group or in serial studies on individual dogs (Table III) and in view of the difficulties in interpretation of data obtained during low rates of sodium excretion, no functional significance has been ascribed to these findings.

The infusion of hypertonic saline has been 
widely employed in studies designed to examine the function of denervated kidneys." Several investigators have found that during such experiments, the denervated kidney excretes a higher percentage of its filtered load of sodium than the contralateral kidney $(8,9)$. In Table IV-A, results of experiments on four dogs with unilaterally transplanted kidneys are shown. Fortuitously, in two of these experiments, filtration rates of the transplanted kidneys were greater than those of the intact organs, and in the other two, the intact kidneys had the greater filtration rates. In none of these animals did the transplanted kidney excrete a greater percentage of filtered sodium than the intact kidney. Thus, in one dog (SP) comparable values were obtained for the two kidneys and in three dogs the values were less for the transplanted than the intact kidneys.

When anesthesia was induced during the course of a brisk sodium diuresis attendant upon hypertonic saline infusion, deviant responses in sodium

4 A detailed review of the pertinent literature may be found in the recent review by Wesson (7). excretion by the two kidneys appeared to be mediated by the respective changes in filtration rate. The plasma sodium levels generally increased throughout such experiments. This term in the filtered load expression, therefore, contributed to a progressive increase in sodium excretion by both kidneys and magnified the effects of small changes in filtration rate on sodium excretion rates. When the GFR of the intact kidney decreased more than that of the transplanted kidney (Figure 2), the percentage of filtered sodium excreted became proportionally greater for the transplanted kidneys. When, however, the GFR decreased more for the transplanted than for the intact kidney (Table II) the opposite relationship was noted.

Expansion of extracellular fluid volume isotonically without changing $\mathrm{Na}$ or $\mathrm{Cl}$ concentrations permits the examination of sodium reabsorption (during high rates of sodium excretion) where changes in filtered load are due entirely to changes in the GFR. Comparison of the response of transplanted kidneys and intact kidneys during

TABLE III

Bilateral values for the glomerular filtration rate, sodium and potassium excretion rates in the fasting state without extracellular fluid expansion (control clearance periods) before and after unilateral transplantation

\begin{tabular}{|c|c|c|c|c|c|c|c|c|c|c|}
\hline \multirow[b]{2}{*}{ Dog } & \multirow{2}{*}{$\begin{array}{c}\text { Day } \\
\text { after } \\
\text { transplant }\end{array}$} & \multicolumn{2}{|c|}{$\underset{m l . / m i n}{\mathrm{Car}_{\text {G }}}$} & \multirow{2}{*}{$\underset{\mathrm{TK}}{\mathrm{Cax} / \mathrm{IK} \dagger}$} & \multicolumn{2}{|c|}{$\underset{\mu E q . / \min }{\mathrm{U}_{\mathrm{Na}}}$} & \multirow{2}{*}{ 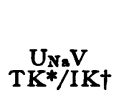 } & \multicolumn{2}{|c|}{$\underset{\mu E q . / \min .}{U_{\mathrm{KV}}}$} & \multirow{2}{*}{$\underset{\mathrm{TK} / \mathrm{UKV}}{\mathrm{TK}^{*} / \mathrm{K}}$} \\
\hline & & TK* & IK $†$ & & $\mathrm{TK}^{*}$ & IK $\dagger$ & & TK* & I K† & \\
\hline \multirow[t]{2}{*}{$\mathrm{RQ}$} & $\begin{array}{l}\text { Pre } \neq \\
\text { Pre }\end{array}$ & $\begin{array}{l}38.1 \\
28.8\end{array}$ & $\begin{array}{l}39.2 \\
35.8\end{array}$ & $\begin{array}{l}0.97 \\
0.80\end{array}$ & $\begin{array}{l}0.67 \\
0.63\end{array}$ & $\begin{array}{l}1.0 \\
1.0\end{array}$ & $\begin{array}{l}0.67 \\
0.63\end{array}$ & $\begin{array}{l}5.7 \\
3.1\end{array}$ & $\begin{array}{l}7.1 \\
2.9\end{array}$ & $\begin{array}{l}0.80 \\
1.07\end{array}$ \\
\hline & 20 & 20.9 & 44.5 & 0.46 & 6.2 & 2.0 & 3.1 & 7.4 & 15.5 & 0.48 \\
\hline \multirow[t]{2}{*}{ SP } & $\begin{array}{l}\text { Pre } \\
\text { Pre }\end{array}$ & $\begin{array}{l}28.4 \\
27.0\end{array}$ & $\begin{array}{l}28.3 \\
27.9\end{array}$ & $\begin{array}{l}1.0 \\
0.97\end{array}$ & 4.4 & 4.7 & 0.94 & $\begin{array}{l}9.1 \\
1.9\end{array}$ & $\begin{array}{r}12.8 \\
1.4\end{array}$ & $\begin{array}{l}0.7 .1 \\
1.36\end{array}$ \\
\hline & $\begin{array}{r}19 \\
123 \\
166\end{array}$ & $\begin{array}{l}12.6 \\
16.4 \\
21.4\end{array}$ & $\begin{array}{l}20.4 \\
19.8 \\
24.1\end{array}$ & $\begin{array}{l}0.62 \\
0.83 \\
0.88\end{array}$ & $\begin{array}{l}7.6 \\
2.7 \\
2.23\end{array}$ & $\begin{array}{l}0.8 \\
1.8 \\
3.8\end{array}$ & $\begin{array}{l}9.5 \\
1.5 \\
0.59\end{array}$ & $\begin{array}{r}6.8 \\
2.3 \\
10.9\end{array}$ & $\begin{array}{r}6.9 \\
3.6 \\
10.3\end{array}$ & $\begin{array}{l}0.99 \\
0.64 \\
1.06\end{array}$ \\
\hline \multirow[t]{2}{*}{ LG } & $\begin{array}{l}\text { Pre } \\
\text { Pre }\end{array}$ & $\begin{array}{l}38.1 \\
34.2\end{array}$ & $\begin{array}{l}37.8 \\
33.4\end{array}$ & $\begin{array}{l}1.01 \\
1.02\end{array}$ & $\begin{array}{l}39.4 \\
13.0\end{array}$ & $\begin{array}{l}34.3 \\
14.9\end{array}$ & $\begin{array}{l}1.15 \\
0.87\end{array}$ & $\begin{array}{l}7.8 \\
4.9\end{array}$ & $\begin{array}{l}8.0 \\
4.7\end{array}$ & $\begin{array}{l}0.98 \\
1.04\end{array}$ \\
\hline & $\begin{array}{l}21 \\
56\end{array}$ & $\begin{array}{l}1.6 \\
4.4\end{array}$ & $\begin{array}{l}41.5 \\
16.1\end{array}$ & $\begin{array}{l}0.04 \\
0.27\end{array}$ & $\begin{array}{l}4.3 \\
2.1\end{array}$ & $\begin{array}{r}13.7 \\
7.3\end{array}$ & $\begin{array}{l}0.31 \\
0.29\end{array}$ & $\begin{array}{l}2.3 \\
2.6\end{array}$ & $\begin{array}{l}24.6 \\
10.8\end{array}$ & $\begin{array}{l}0.09 \\
0.24\end{array}$ \\
\hline \multirow[t]{2}{*}{$A N$} & $\begin{array}{l}\text { Pre } \\
\text { Pre }\end{array}$ & $\begin{array}{l}41.8 \\
36.7\end{array}$ & $\begin{array}{l}42.3 \\
36.6\end{array}$ & $\begin{array}{l}0.99 \\
1.00\end{array}$ & $\begin{array}{l}2.2 \\
4.7\end{array}$ & $\begin{array}{l}1.3 \\
4.3\end{array}$ & $\begin{array}{l}1.69 \\
1.09\end{array}$ & $\begin{array}{r}13.4 \\
8.0\end{array}$ & $\begin{array}{r}13.1 \\
9.9\end{array}$ & $\begin{array}{l}1.02 \\
0.81\end{array}$ \\
\hline & $\begin{array}{r}8 \\
22\end{array}$ & $\begin{array}{l}10.1 \\
25.5\end{array}$ & $\begin{array}{l}42.8 \\
25.9\end{array}$ & $\begin{array}{l}0.24 \\
0.98\end{array}$ & $\begin{array}{l}1.8 \\
2.3\end{array}$ & $\begin{array}{l}2.1 \\
7.2\end{array}$ & $\begin{array}{l}0.86 \\
0.32\end{array}$ & 20 & $\begin{array}{r}3.1 \\
21.9\end{array}$ & $\begin{array}{l}2.0 \\
0.91\end{array}$ \\
\hline
\end{tabular}

* TK $=$ Transplanted kidney.

† IK = Intact kidney.

$\ddagger$ Pre = Pretransplantation studies. 
TABLE IV

Glomerular filtration, sodium and potassium excretion rates in transplanted and intact kidneys *

\begin{tabular}{|c|c|c|c|c|c|c|c|c|c|c|c|c|}
\hline \multirow[b]{2}{*}{ Dog } & \multirow{2}{*}{$\begin{array}{c}\text { Day } \\
\text { following } \\
\text { transplant }\end{array}$} & \multicolumn{2}{|c|}{$\cos t$} & \multirow{2}{*}{$\underset{\mathrm{TK} / \mathrm{IK}}{\mathrm{C}_{\mathrm{Cr}}}$} & \multicolumn{2}{|c|}{$\underset{\mu E q . / \min }{\mathrm{U}_{\mathrm{NaV}} \dagger}$} & \multirow{2}{*}{$\begin{array}{c}\mathrm{U}_{\mathrm{NaV}} \\
\mathrm{TK} / \mathrm{IK}\end{array}$} & \multicolumn{2}{|c|}{$\begin{array}{c}\mathrm{Na} \\
\text { Per cent of filtered } \\
\text { load excreted }\end{array}$} & \multicolumn{2}{|c|}{$\underset{\mu E q . / \min .}{U_{\mathrm{KV}}}$} & \multirow{2}{*}{$\underset{\mathrm{TK} / \mathrm{IK}}{\mathrm{UKV}_{\mathrm{KV}}}$} \\
\hline & & TK† & $\mathrm{IK \dagger}$ & & TK & IK & & TK & IK & TK & IK & \\
\hline \multicolumn{13}{|c|}{ A. During infusion of $3 \% \mathrm{NaCl}$ at $5.0 \mathrm{ml} . / \mathrm{min}$. } \\
\hline $\begin{array}{l}\text { PW } \\
\text { AN } \\
\text { LG } \\
\text { SP }\end{array}$ & $\begin{array}{r}21 \\
21 \\
56 \\
125\end{array}$ & $\begin{array}{r}21.5 \\
39.8 \\
7.7 \\
29.1\end{array}$ & $\begin{array}{l}14.0 \\
35.3 \\
26.4 \\
40.9\end{array}$ & $\begin{array}{l}1.54 \\
1.13 \\
0.29 \\
0.71\end{array}$ & $\begin{array}{c}221 \\
86.8 \\
127 \\
618\end{array}$ & $\begin{array}{l}186 \\
295 \\
482 \\
883\end{array}$ & $\begin{array}{l}1.19 \\
0.29 \\
0.26 \\
0.70\end{array}$ & $\begin{array}{r}7.0 \\
1.4 \\
10.2 \\
14.3\end{array}$ & $\begin{array}{r}8.6 \\
5.5 \\
11.4 \\
14.0\end{array}$ & $\begin{array}{l}36 \\
16.5 \\
11.3 \\
32\end{array}$ & $\begin{array}{l}23.1 \\
29.8 \\
36.6 \\
47.2\end{array}$ & $\begin{array}{l}1.56 \\
0.55 \\
0.31 \\
0.68\end{array}$ \\
\hline \multicolumn{13}{|c|}{ B. During infusion of isotonic solution at $8.8 \mathrm{ml} . / \mathrm{min}$. } \\
\hline $\begin{array}{l}\text { AN } \\
\text { SP } \\
\text { RQ } \\
\text { SP }\end{array}$ & $\begin{array}{r}8 \\
19 \\
20 \\
123\end{array}$ & $\begin{array}{r}9.1 \\
18.2 \\
24.6 \\
23.9\end{array}$ & $\begin{array}{l}47.7 \\
32.7 \\
51.9 \\
33.2\end{array}$ & $\begin{array}{l}0.19 \\
0.56 \\
0.47 \\
0.72\end{array}$ & $\begin{array}{r}5.2 \\
125.0 \\
24.3 \\
165.4\end{array}$ & $\begin{array}{r}101.6 \\
23.7 \\
6.6 \\
280.3\end{array}$ & $\begin{array}{l}0.05 \\
5.27 \\
3.68 \\
0.59\end{array}$ & $\begin{array}{l}0.49 \\
7.16 \\
0.79 \\
5.04\end{array}$ & $\begin{array}{l}1.51 \\
1.05 \\
0.10 \\
6.13\end{array}$ & $\begin{array}{r}3.2 \\
18.5 \\
14.2 \\
10.7\end{array}$ & $\begin{array}{r}7.2 \\
14.4 \\
15.3 \\
12.8\end{array}$ & $\begin{array}{l}0.44 \\
1.28 \\
0.93 \\
0.84\end{array}$ \\
\hline
\end{tabular}

* Data are mean values for three to nine clearance periods and do not include control periods. Solution used for isotonic expansion was a simulated ECF, containing $\mathrm{Na}, \mathrm{Cl}, \mathrm{K}, \mathrm{HCO}_{3}$, and glucose. Urinary losses of electrolytes and water were replaced during the experiment (see text).

$\dagger$ See footnotes to previous tables for meanings of these abbreviations.

these experiments revealed differences between the two kidneys, but there was no consistent abnormality noted in the patterns of the transplanted kidneys.

In Table IV-B results are shown for four experiments on three dogs. In two studies the percentage of filtered sodium excreted was greater for the transplanted kidney and in two slight to marked superiority of sodium excretion was exhibited by the intact kidney.

Wesson, Anslow, Raisz, Bolomey, and Ladd (6) have noted that if one selects successive points during isotonic expansion where the GFR and plasma sodium concentrations are identical (hence

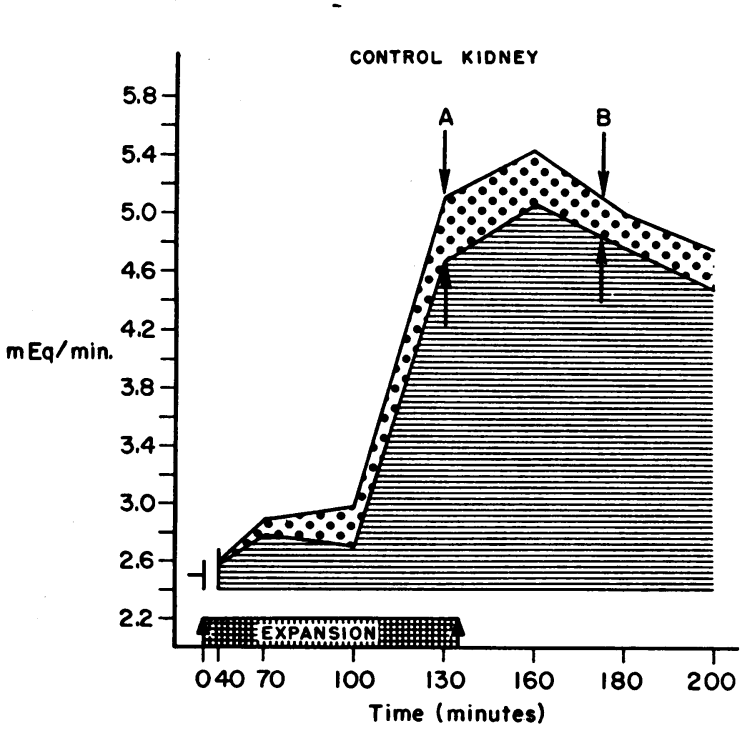

A

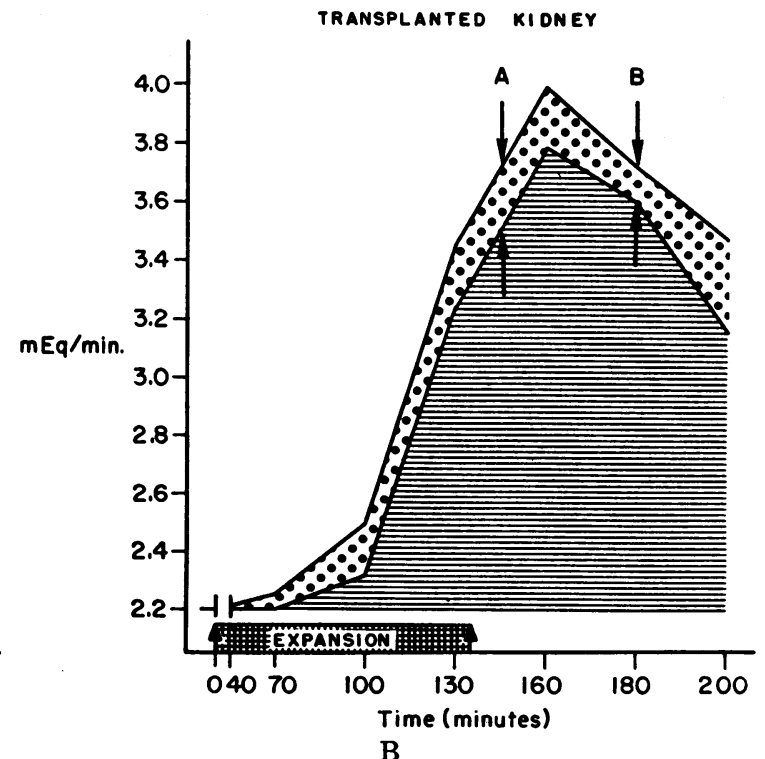

B

Fig. 4. Na Reabsorption During Isotonic Expansion of ECF

Entire area under outer curve represents filtered load of sodium; stipled area, Na excreted; cross-hatched area, $\mathrm{Na}$ reabsorbed. Time refers to minutes following onset of expansion (see text for details). Values for the three control periods are not included. 
TABLE V

Summary of experiments on dogs with one kidney denervated by conventional means *

\begin{tabular}{|c|c|c|c|c|c|c|c|c|c|c|c|c|c|}
\hline \multirow[b]{2}{*}{ Dog } & \multirow[b]{2}{*}{ Experiment } & \multirow{2}{*}{$\begin{array}{c}\text { Day } \\
\text { following } \\
\text { denerva- } \\
\text { tion }\end{array}$} & \multicolumn{2}{|c|}{$\underset{m l . / m i n}{\mathrm{C}_{\mathrm{C}_{\mathrm{r}}}}$} & \multirow{2}{*}{$\underset{\mathrm{DK} / \mathrm{TK}}{\mathrm{C}}$} & \multicolumn{2}{|c|}{$\underset{\mu E q . / m i n}{\mathrm{U}_{\mathrm{NaV}}}$} & \multicolumn{2}{|c|}{$\begin{array}{l}\text { Per cent FL } \mathrm{Fa}_{\mathrm{Na}} \\
\text { excreted }\end{array}$} & \multirow{2}{*}{$\begin{array}{c}\text { Percent } \\
\text { FL } L_{\mathrm{Na}} \\
\text { excreted } \\
\text { DK/IK }\end{array}$} & \multicolumn{2}{|c|}{$\underset{\mu E q . / \min .}{\mathrm{UKV}_{\mathrm{KV}}}$} & \multirow{2}{*}{$\begin{array}{c}\mathrm{UKV}_{\mathbf{K}} \mathrm{V} \\
\mathrm{DK} / \mathrm{IK}\end{array}$} \\
\hline & & & DK† & I K† & & $\mathrm{DK}$ & IK & DK & IK & & DK & IK & \\
\hline \multirow[t]{2}{*}{$\mathrm{HA}$} & \multirow{2}{*}{$\begin{array}{l}\text { Isotonic expansion } \\
\text { Isotonic expansion } \\
\text { I.V. thiomerin } \\
3 \% \mathrm{NaCl} \\
\text { (a) before anes. } \\
\text { (b) after anes. }\end{array}$} & \multirow[t]{2}{*}{$\begin{array}{l}\text { Pre } \\
11 \\
29 \\
52\end{array}$} & $\begin{array}{r}43.3 \\
25.9 \\
8.3\end{array}$ & $\begin{array}{l}43.4 \\
45.9 \\
16.4\end{array}$ & $\begin{array}{l}1.0 \\
0.56 \\
0.51\end{array}$ & $\begin{array}{r}308 \\
147 \\
95\end{array}$ & $\begin{array}{l}232 \\
212 \\
147\end{array}$ & $\begin{array}{l}5.2 \\
3.8 \\
7.6\end{array}$ & $\begin{array}{l}4.1 \\
3.2 \\
6.7\end{array}$ & $\begin{array}{l}1.27 \\
1.19 \\
1.14\end{array}$ & $\begin{array}{l}55 \\
22.1 \\
15.8\end{array}$ & $\begin{array}{l}47.4 \\
31.5 \\
16.2\end{array}$ & $\begin{array}{l}1.16 \\
0.70 \\
0.98\end{array}$ \\
\hline & & & $\begin{array}{l}29.3 \\
25.6\end{array}$ & $\begin{array}{l}53.6 \\
50.2\end{array}$ & $\begin{array}{l}0.53 \\
0.51\end{array}$ & $\begin{array}{l}184 \\
348\end{array}$ & $\begin{array}{l}336 \\
530\end{array}$ & $\begin{array}{l}4.2 \\
8.4\end{array}$ & $\begin{array}{l}4.3 \\
7.3\end{array}$ & $\begin{array}{l}0.98 \\
1.15\end{array}$ & $\begin{array}{l}18.0 \\
18.6\end{array}$ & $\begin{array}{l}36.4 \\
32.3\end{array}$ & $\begin{array}{l}0.49 \\
0.58\end{array}$ \\
\hline \multirow[t]{2}{*}{ VA } & \multirow{2}{*}{$\begin{array}{l}\text { Isotonic expansion } \\
\text { I.V. thiomerin } \\
\text { Isotonic expansion } \\
3 \% \mathrm{NaCl} \\
\text { (a) before anes. } \\
\text { (b) after anes. }\end{array}$} & \multirow[t]{2}{*}{$\begin{array}{c}\text { Pre } \\
7 \\
12 \\
21\end{array}$} & $\begin{array}{l}37.4 \\
32.4 \\
52.9\end{array}$ & $\begin{array}{l}40.7 \\
34.6 \\
48.5\end{array}$ & $\begin{array}{l}0.92 \\
0.94 \\
1.09\end{array}$ & $\begin{array}{l}222 \\
344 \\
242\end{array}$ & $\begin{array}{l}206 \\
385 \\
273\end{array}$ & $\begin{array}{l}3.5 \\
8.0 \\
3.0\end{array}$ & $\begin{array}{l}3.3 \\
8.5 \\
3.9\end{array}$ & $\begin{array}{l}1.06 \\
0.94 \\
0.77\end{array}$ & $\begin{array}{l}20.1 \\
32.3 \\
15.5\end{array}$ & $\begin{array}{l}19.8 \\
32.6 \\
15.6\end{array}$ & $\begin{array}{l}1.01 \\
0.99 \\
0.99\end{array}$ \\
\hline & & & $\begin{array}{l}35.0 \\
41.0\end{array}$ & $\begin{array}{l}33.8 \\
32.1\end{array}$ & $\begin{array}{l}1.04 \\
1.32\end{array}$ & $\begin{array}{l}170 \\
448\end{array}$ & $\begin{array}{l}213 \\
246\end{array}$ & $\begin{array}{l}3.4 \\
7.4\end{array}$ & $\begin{array}{l}4.5 \\
5.2\end{array}$ & $\begin{array}{l}0.76 \\
1.42\end{array}$ & $\begin{array}{l}20.8 \\
20.8\end{array}$ & $\begin{array}{l}25.2 \\
11.2\end{array}$ & $\begin{array}{l}0.83 \\
1.86\end{array}$ \\
\hline
\end{tabular}

* One predenervation experiment is included for each animal. Data are mean values for three to seven clearance periods and do not include control periods. tables.

$\dagger$ DK refers to denervated kidneys, IK to intact kidneys. For all other abbreviations see footnotes to previous

filtered loads are identical), the absolute rate of sodium reabsorption increases with time. On the basis of this observation, it has been suggested that the intrinsic reabsorptive capacity of the tubules increases in the dog as a function of volume expansion. In Figure 4, the results of the second experiment on Dog SP (Table IV-B) are depicted in the manner of Wesson and his colleagues for both the transplanted and intact kidneys. Comparing the rate of reabsorption at point $\mathrm{B}$ with point $A$ in each diagram suggests that sodium reabsorption increased with time not only in the intact kidney but also in the transplanted kidney.

\section{Denervated nontransplanted kidneys}

Eleven clearance studies were performed on two dogs denervated by conventional means. The results of one control and three postdenervation experiments on each animal are shown in Table V. In one of the dogs, the GFR of the denervated kidney decreased from its preoperative level $;^{5}$ in the other, values for the two kidneys remained comparable after denervation. The results of these experiments do not differ in any major respect from those on the dogs in which one kidney was autotransplanted.

5 This may have been a consequence of the fact that alcohol was injected into the adventitia of the renal artery to insure denervation.

\section{DISCUSSION}

The present studies were undertaken with a twofold purpose: 1) to further define the functional capabilities of the transplanted kidney, and 2) to examine the relationship between renal nerves and sodium excretion.

Experiments were performed on dogs with permanent hemibladders in which one kidney was autotransplanted and the opposite kidney left intact. Several properties of this preparation support its usefulness in such an investigation: 1) construction of two separate urinary bladders provides the opportunity to study the functions of both kidneys in a single animal simultaneously and serially; 2) autotransplantation of one kidney only permits comparison of the data of the transplanted organ both with its own pretransplantation values and with the concurrent responses of the intact organ; 3) the removal of a kidney from the body of the host during the transplantation procedure results in the severing of all renal nerves without interrupting nerves to extrarenal splanchnic structures.

The results obtained serve to reinforce the impression gained from human observations (3) that a kidney, successfully transplanted, may function in most respects in a normal manner. The one major abnormality noted in the function of the autotransplanted kidney in the dog was a decrease 
in glomerular filtration rate and renal plasma flow in the initial studies following transplantation. This defect did not persist, however, and in two animals the value for the GFR of the transplanted kidney ultimately came to equal that of the intact kidney. It seems probable that the initial decrease in clearance values resulted either from the period of anoxia sustained by the kidney during transplantation or from a temporary decrease in arterial or venous lumina at the anastamotic sites.

In recent years, interest has been reawakened in the possible influence of renal nerves on the tubular transport of sodium. In studies on dogs with one kidney denervated and the opposite one intact, the denervated organ has frequently been noted to excrete more sodium than the intact kidney. On the basis of the higher rates of sodium excretion by the denervated kidney, it has been suggested that renal nerves exert a specific effect on the renal tubular reabsorptive capacity for sodium chloride (8). In the majority of instances where differences in sodium excretion rates have existed, however, the denervated kidney has had a slightly greater filtration rate than the contralateral organ. It has been contended by several groups that the differences in the GFR (and thus the filtered loads of sodium) have been of sufficient magnitude to account for the differences in sodium excretion $(10,11)$. To date this conflict in interpretation has not been resolved.

In the majority of experiments performed in the present studies, filtration rate of the denervated kidney was less than the simultaneous value of the intact organ. A higher rate of sodium excretion by the transplanted kidney would, therefore, provide strong evidence in favor of a defect in tubular sodium reabsorptive capacity. Such evidence was not found. When sodium excretion rates were factored by their respective filtered loads, the ratios were not consistently greater for the transplanted kidneys and in several experiments they were less.

Expansion of extracellular fluid volume by infusion of 3 per cent sodium chloride resulted in the elaboration of a sodium-rich urine by both kidneys. In the unanesthetized state there was no evidence for impaired tubular reabsorption by the transplanted kidney. When anesthesia was induced the differences in sodium excretion between the two kidneys were explicable on the basis of concurrent changes in the respective glomerular filtration rates. When the GFR of the intact kidney decreased more than that of the transplanted kidney, superiority of sodium excretion (either relative to the filtered load or absolute) was exhibited by the transplanted kidney (Figure 2). Conversely, when the GFR of the transplanted kidney decreased more than that of the intact kidney (Table II), the opposite response was noted.

When the plasma sodium concentration was maintained constant and the filtered load of sodium rose due to increasing filtration rates (during isotonic expansion of ECF), the opportunity existed to investigate the effects of GFR on sodium excretion in transplanted and intact kidneys. Although differences in sodium excretion between the two kidneys were noted, these were not consistent in direction and no abnormal pattern for the transplanted kidney became apparent. In a dog studied five months after autotransplantation, expansion of ECF volume appeared to enhance tubular reabsorptive capacity for sodium not only in the intact kidney but also in the transplanted kidney.

The response of kidneys denervated by a conventional procedure (as described above) did not differ materially from that of kidneys denervated by autotransplantation. It, therefore, seems reasonable to conclude that denervation by conventional means provides satisfactory experimental models.

One theoretic objection to long-term studies on kidneys denervated by all procedures including transplantation is the possibility that nerve fibers may regenerate. Regeneration of nerve fibers into nerve tracts in the transplanted kidney has not yet been systematically investigated. Should this occur to any significant degree, it would not be expected until after the original nerve fibers had degenerated. In two-thirds of the present studies, data were obtained within three weeks of transplantation, and hence this objection would not apply. In the remaining studies, it cannot be asserted that regenerating fibers did not enter the kidney. Whether fibers from the iliac vessels (the sites of vessel anastomoses) could be expected to provide "normal" innervation for a kidney is beyond the scope of this discussion. However, the results of the more chronic experiments did not 
differ consistently from the larger number of earlier studies.

\section{SUMMARY AND CONCLUSIONS}

Separate but simultaneous studies have been performed on the two kidneys of six dogs having one kidney autotransplanted into the iliac fossa and the opposite kidney intact. Data have been examined to obtain further information about $a$ ) the functional capacity of the transplanted kidney and, $b$ ) the effects of denervation (imposed by the transplantation procedure) on the tubular transport of sodium chloride. Serial studies were also performed on two dogs in which unilateral denervation was accomplished by a conventional procedure.

The results suggest 1 ) the autotransplanted kidney in the dog demonstrated no persistent defect in any of the functional parameters examined, 2) complete denervation occurring during the transplantation procedure did not result in any consistent abnormality in the tubular transport of sodium chloride, and 3) the responses of the conventionally denervated kidneys did not differ in any major respect from the autotransplanted kidneys. Conventional denervation as employed in numerous previous studies, therefore, appears to be a satisfactory means of depriving the kidney of its nerve supply.

The possibility of nerve regeneration in the transplanted kidney has not yet been definitively studied. However, no consistent differences were noted between the long-term studies and those performed within three weeks of transplantation.

\section{ACKNOWLEDGMENTS}

The authors wish to thank Mrs. Antionett d'Angelo, Miss Nancy Chilson and Mr. Arthur Bloom for technical assistance; Dr. Warren R. Guild and Dr. Nancy
Boucot for assistance with certain experiments; Dr. Joseph E. Murray for performing several of the transplantation procedures; and Dr. Gustave J. Dammin, Dr. Nathan Couch and Dr. M. G. Pace for pathologic examination of biopsy and postmortem specimens of the kidneys in the dogs included in the present study.

\section{REFERENCES}

1. Quinby, W. C. The function of the kidney when deprived of its nerves. J. exp. Med. 1916, 23, 535.

2. Smith, H. W. The Kidney, Structure and Function in Health and Disease. New York, Oxford University Press, 1951.

3. Bricker, N. S., Guild, W. R., Reardan, J. B., and Merrill, J. P. Studies on the functional capacity of a denervated homotransplanted kidney in an identical twin with parallel observations in the donor. J. clin. Invest. 1956, 35, 1364.

4. Desautels, R. Personal communication.

5. Murray, J. E., Lang, S., Miller, B. F., and Dammin, G. J. Prolonged functional survival of renal autotransplants in the dog. Surg. Gyn. Obstet. 1956, $103,15$.

6. Wesson, L. G., Jr., Anslow, W. P., Jr., Raisz, L. G., Bolomey, A. A., and Ladd, M. Effect of sustained expansion of extracellular fluid volume upon filtration rate, renal plasma flow and electrolyte and water excretion in the dog. Amer. J. Physiol. 1950, 162,677 .

7. Wesson, L. G., Jr. Glomerular and tubular factors in the renal excretion of sodium chloride. Medicine 1957, 36, 281.

8. Kaplan, S. A., and Rapoport, S. Urinary excretion of sodium and chloride after splanchnicotomy; effect on the proximal tubule. Amer. J. Physiol. $1951,164,175$.

9. Kriss, J. P., Futcher, P. H., and Goldman, M. L. Unilateral adrenalectomy, unilateral splanchnic nerve resection and homolateral renal function. Amer. J. Physiol. 1948, 154, 229.

10. Berne, R. M. Hemodynamics and sodium excretion of denervated kidney in anesthetized and unanesthetized dog. Amer. J. Physiol. 1952, 171, 148.

11. Page, L. B., Baxter, C. F., Reem, G. H., Scott-Baker, J. C., and Smith, H. W. Effect of unilateral splanchnic nerve resection on the renal excretion of sodium. Amer. J. Physiol. 1954, 177, 194. 